\title{
Caring methods of male and female Holstein breed cattle and improving high-productive cattle herds in the condition of Uzbekistan
}

\author{
M. Dosmukhamedova ${ }^{1, *}, A$. Esanov $^{1}, K$. Shakirov $^{1}$, and $U$. Khodjayev $^{2}$ \\ ${ }^{1}$ Tashkent State Agrarian University, Universitetskaya str., 2, 100140, Tashkent, Uzbekistan \\ ${ }^{2}$ Tashkent branch of Samarkand Institute of Veterinary Medicine, Tashkent, Uzbekistan
}

\begin{abstract}
In this article, the conditions of keeping cattle of different ages on the farm were studied towards satisfying the demand of the population of the Republic for milk and dairy products. Biological methods of zootechnical selection and adaptation to the external environment, growth and development of cattle, identification of external characteristics, and preparation of heifers for breeding, milking of first-generation cows and economic efficiency were determined in the experiment. The nutrients consumed was different in the experimental groups. It was assumed that group I was $100 \%$, group II was equal to $105.4 \%$ and group III was equal to 110.1 feed units. Per $1 \mathrm{~kg}$ of feed per group was 183, 183, 185 grams, respectively. The protein-sugar ratio was $1: 0.47-0.48$. Dry matter per $1 \mathrm{~kg}$ of feed unit was 1.17-1.20 kg, followed by 12.2-12.5 MJ of exchange energy, 362-370 grams of fiber and 87-90 grams of sugar. Improvement of cattle had a positive effect on the rise of their living mass and the improvement of their exterior properties.
\end{abstract}

\section{Introduction}

The livestock sector is one of the leading sectors in the provision of milk, meat, eggs, honey and other types of products to the population in the countries of the world. Currently, a number of countries such as the United States, Canada, Germany, the Netherlands and Israel occupy a special place in the introduction of modern innovative technologies into the livestock sector $[4-5,13]$. According to the experience of the world community, the indicator of cows of the Holstein breed in terms of milk yield is high, and from each head of cattle during lactation, 9.0-9.5 thousand kilograms of milk is obtained, and the fat content in milk is 4.5-4.6 percent. In developed foreign countries, scientific research is being carried out aimed at further improving the milk yield of cows with the Holstein genotype and the indicators of precipitation in it $[11,15]$. The main goal will be to achieve positive productivity by increasing milk health and fat content of cows in groups with high genotypes.

\footnotetext{
*Corresponding author: Dmuxayyoxon@mail.ru
} 
A number of measures are being taken to radically reform and further develop the livestock sector in the Republic. Special attention is paid to the creation of fertile herds by increasing the production of livestock products, including milk, the creation of food reserves in the personal assistant, farmer and farmer farms, the establishment of breeding works, the generation of cattle genetic opportunities and the introduction of advanced technologies into the field. The Action Strategy of the Republic of Uzbekistan for 20172021 on "consistent development of agricultural production, further strengthening food security, rapid development of animal husbandry, meeting the growing demand of the population for livestock products" was adopted [1]. Furthermore, resolution of the President of the Republic of Uzbekistan No. PP-4243 of March 18, 2019 "On measures for further development and support of the livestock sector" and December 29, 2015 "On measures for further reform and development of agriculture in 2016-2020" Resolution No. PQ-2460" were adopted towards promoting and strengthening the production of livestock products in the country [2-3].

A number of research works have been carried out on the zoning of black-and-white Holstein genotype cattle and increasing milk productivity, improving their breeding and productivity qualities. Furthermore, foreign scientists, such as S. Brody, J.C. Bonsma, D.E. Dowling, J.E. Johnston, G.G. Carzneiro, J. Findlay, A.O. Rhoad, K. Phillips, K.G. Akhmadaliev, F.F. Eysner, P. Proxorenko, K.F. Kushner were conducted research in the field of livestock breeding. Uzbek scientists, including Sh.A.Akmalkhanov, E.Yu.Karchevsky, N.A.Mavlyanov, U.N.Nosirov, A.A.Atboshyan, A.Kakharov, M.I.Ashirov, B.A.Abdalniyazov, M. H.Domukhamedova, K.J.Shakirov, M.Norbaeva, stated that in the study of adaptation of black-and-white Holstein genotype cattle to the environment, it was possible to breed cattle of different Holstein genotype types [5-10]. The focused technology of breeding, their selection and selection methods of the first $(1 / 2-$ $\left.1 / 2 G^{\prime} 1\right)$ and the second (1/4-3/4 G'2) hybridized generation of Holstein as well as young cows, buds and first-born cows of Chinese Holstein breed have not yet been studied [1415]. Therefore, in the field of farming, research is needed to develop technologies for intensive care and preparation of calves, females and heifers of black-and-white Holstein and various types of Holstein, as well as creation of productive herds [11-12]. This research was aimed at care of bull and heifers in a focused technology, the formation of their productive herd of cows, the discovery of genetic potential for productivity, the selection of the first high-yielding leading cows and the repair of the "breeding core".

\section{Materials and methods}

The research was conducted at the Rokhatoy breeding farm in Tashkent district, Tashkent region, and in this research, black cattle and black-and-white Holstein genotypes, young females, first-born cows and high-yielding cows were selected during 2012-2019.

The research was carried out by zootechnical, biological and statistical methods. Each experimental farm took into account the storage systems, feeding norms and types of cows of different Holstein genotypes [5-9]. Evaluation of the exterior of cattle was carried out on a scale of 9 and 100 points, based on clinical indicators EA Arzumanyan (1957), heat resistance Yu.O. Raushenbach (1975), hemoglobin Sali, based on milk yield, determination of fat content in milk, control milking the number of erythrocytes and leukocytes was determined in the Goryaev chamber [10-13]. Feeding of milk was carried out by the method of V.E. Nedava (1966), the obtained materials were processed by biometric methods of E.K. Merkureva (1970). According to the results of the study, the analytical method, the accuracy of the experiment, the reliability of the difference in the range of selection traits (R), the correlation (r) in the range of productivity selection traits, as well as the heat resistance index (ICI) were studied $[5-8,10]$. 


\section{Results and discussion}

In the growth and development of cattle, the growth rate of the tissues present in it - bone, muscle, and adipose tissue corresponds to certain periods of their age. In particular, the 6-9month-old calving period was April-July, when the weather conditions did not adversely affect calf storage, with positive use of solar radiation, resting in shady cool areas of trees. The 10-15 month period of the bodies coincided with August-March. All of the bodies in the experiment $(n=30)$ were stored in a group with free spread in the open field $[10,11]$. The animals were 3 meters wide and 4 meters high on the feeding front. The cattle were fed and protected from air precipitation and solar radiation. They were mostly kept in the shade of the trees to rest during the hot days of the day. The distribution area averaged $12 \mathrm{~m}^{2}$ per property $[13,14]$. When keeping young cattle on light awnings, the air temperature under the awning was determined for all seasons (Table 1). Humidity and wind speed varied somewhat throughout the season. The average temperature was $16.8^{\circ} \mathrm{C}$ in spring, $28.9^{\circ} \mathrm{C}$ in summer, $18^{\circ} \mathrm{C}$ in autumn and $0.1^{\circ} \mathrm{C}$ in winter, and it can be said that climate was optimal.

Table 1. Seasonal changes in the microclimate under the awnings in the open areas of group storage of young experimental cattle.

\begin{tabular}{|c|c|c|c|c|c|}
\hline \multicolumn{2}{|c|}{ Indicators } & Spring & Summer & Autumn & Winter \\
\hline \multirow{2}{*}{ Temperature, ${ }^{\circ} \mathrm{C}$} & Average & 16.8 & 28.9 & 18.0 & 0.1 \\
\cline { 2 - 6 } & Lim & $-2-(+30)$ & $17.0-40.5$ & $11.5-28.5$ & $-19-(+5)$ \\
\hline \multirow{2}{*}{ Humidity, \% } & Average & 74.0 & 44.5 & 65.2 & 78.5 \\
\cline { 2 - 6 } & Lim & $58-90$ & $29-58$ & $45-80$ & $61-90$ \\
\hline \multirow{2}{*}{$\begin{array}{c}\text { Wind speed } \\
\mathrm{m} / \mathrm{sec} .\end{array}$} & Average & 4.8 & 3.5 & 4.3 & 5.2 \\
\cline { 2 - 6 } & Lim & $0.85-7.5$ & $0.6-8.0$ & $0.6-8.7$ & $1.1-9.2$ \\
\hline
\end{tabular}

The nutrient content of coarse, blue, juicy and concentrated feeds consumed during the care of young cattle in the experimental groups at 6-27 months of age was 2997 feed units in group I, 3160 feed units in group II and 3301 feed units in group III. The nutrients consumed was different in the experimental groups. It was assumed that group I was $100 \%$, group II was equal to $105.4 \%$ and group III was equal to 110.1 feed units. Per $1 \mathrm{~kg}$ of feed per group was 183, 183, 185 grams, respectively. The protein-sugar ratio was 1: 0.47-0.48. Dry matter per $1 \mathrm{~kg}$ of feed unit was $1.17-1.20 \mathrm{~kg}$, followed by 12.2-12.5 MJ of exchange energy, 362-370 grams of fiber and 87-90 grams of sugar. Improvement of cattle had a positive effect on the rise of their living mass and the improvement of their exterior properties. It is known that young cattle grow in weight and size during development. When their weight gain was weighed on a monthly basis, it was found that live weight was changed monthly and average daily weight gained (Table 2).

Table 2. Live weight change of young cattle in experimental groups, $\mathrm{kg}(\mathrm{X} \pm \mathrm{Sx})$.

\begin{tabular}{|c|c|c|c|c|c|c|}
\hline \multirow{2}{*}{$\begin{array}{c}\text { Age } \\
\text { (month) }\end{array}$} & \multicolumn{7}{|c|}{ Experimental groups } \\
\cline { 2 - 7 } & \multicolumn{2}{|c|}{$\mathbf{I}(\mathbf{n}=\mathbf{1 0})$} & \multicolumn{2}{c|}{ II (n=10) } & \multicolumn{2}{c|}{ III (n=10) } \\
\cline { 2 - 7 } & $\mathrm{X} \pm \mathrm{S}$ & $\mathrm{C}_{\mathrm{v}}$ & $\mathrm{X} \pm \mathrm{S}$ & $\mathrm{C}_{\mathrm{v}}$ & $\mathrm{X} \pm \mathrm{S}$ & $\mathrm{C}_{\mathrm{v}}$ \\
\hline $\mathbf{6}$ & $152.8 \pm 1.5$ & 3.16 & $155.1 \pm 2.1$ & 2.72 & $159.1 \pm 2.2$ & 6.20 \\
\hline $\mathbf{9}$ & $208.5 \pm 2.5$ & 3.50 & $214.4 \pm 4.1$ & 3.01 & $225.0 \pm 3.5$ & 4.02 \\
\hline $\mathbf{1 2}$ & $261.5 \pm 3.7$ & 3.98 & $265.3 \pm 4.2$ & 3.65 & $280.0 \pm 4.5$ & 9.62 \\
\hline $\mathbf{1 5}$ & $307.1 \pm 2.9$ & 4.01 & $322.0 \pm 3.7$ & 4.07 & $338.0 \pm 3.1$ & 7.89 \\
\hline $\mathbf{1 8}$ & $351.0 \pm 3.0$ & 2.76 & $366.0 \pm 3.7$ & 3.64 & $384.0 \pm 2.8$ & 6.18 \\
\hline $\mathbf{2 1}$ & $395.5 \pm 6.0$ & 5.51 & $411.6 \pm 5.0$ & 5.71 & $430.0 \pm 2.9$ & 5.44 \\
\hline $\mathbf{2 4}$ & $440.0 \pm 3.2$ & 7.30 & $456.0 \pm 4.0$ & 12.56 & $485.6 \pm 4.5$ & 10.13 \\
\hline $\mathbf{2 6 - 2 8}$ & $494.5 \pm 3.2$ & 6.69 & $513.5 \pm 4.0$ & 14.26 & $542.5 \pm 4.5$ & 3.60 \\
\hline
\end{tabular}


The live weight of calves collected in the experimental groups at 6 months was $152.8 \mathrm{~kg}$ in group I, $155.1 \mathrm{~kg}$ in group II and $159.1 \mathrm{~kg}$ in group III ( $\mathrm{P}>0.95-0.999)$. These calves differed in live weight, Group III was predominant, weighing $6.3 \mathrm{~kg}(2.96 \%)$ and $4.0 \mathrm{~kg}$ (2.51\%). At 12 months, $18.5 \mathrm{~kg}(6.61 \%), 14.7 \mathrm{~kg}(5.25 \%)$, at 18 months $33 \mathrm{~kg}(8.59 \%)$ and $15 \mathrm{~kg}(3.91 \%)$, at 24 months $45.6 \mathrm{~kg}(9.39 \%)$ and $29.6 \mathrm{~kg}(6.10 \%)$ respectively (P>0.9990.9999 ). The live weight of group II bodies was $2.3 \mathrm{~kg}, 3.8,15.0 \mathrm{~kg}$, and $16.0 \mathrm{~kg}$ higher than those in group I at all growth periods $(\mathrm{P}>0.999)$.

Table 3. Body growth in experimental groups covered by nutrients.

\begin{tabular}{|c|c|c|c|c|c|c|}
\hline \multirow{3}{*}{$\underset{\text { (month) }}{\text { Age }}$} & \multicolumn{2}{|c|}{ I } & \multicolumn{2}{|c|}{ II } & \multicolumn{2}{|c|}{ III } \\
\hline & \multicolumn{6}{|c|}{1 kg spent on absolute weight gain } \\
\hline & $\begin{array}{c}\text { Feed } \\
\text { unit, kg }\end{array}$ & $\begin{array}{l}\text { Digestible } \\
\text { protein, } g\end{array}$ & $\begin{array}{c}\text { Feed unit, } \\
\text { kg }\end{array}$ & $\begin{array}{l}\text { Digestible } \\
\text { protein, } g\end{array}$ & $\begin{array}{c}\text { Feed } \\
\text { unit, kg }\end{array}$ & $\begin{array}{l}\text { Digestible } \\
\text { protein, } g\end{array}$ \\
\hline $6-12$ & 7.00 & 1242 & 7.25 & 1270 & 6.98 & 1274 \\
\hline 13-18 & 9.09 & 1730 & 8.54 & 1639 & 8.74 & 1693 \\
\hline 19-27 & 9.91 & 1812 & 10.17 & 1864 & 9.77 & 1779 \\
\hline 6-27 & 8.77 & 1610 & 8.82 & 1616 & 8.61 & 1596 \\
\hline
\end{tabular}

In terms of body size growth, first- and second-generation cattle of the black-and-white Holstein genotype in groups I and II did not lag far behind purebred Chinese Holsteins (Figure 1). Sitting bone width and pelvic width rose similarly to group III. Hence, in groups II-III, body enlargement was more pronounced with elevation of the Holstein genotype. This condition is characteristic of the body growth behavior of mature cows. Changes have been made to the farm's agenda, taking into account the feeding movements of the cattle and their resting movements.

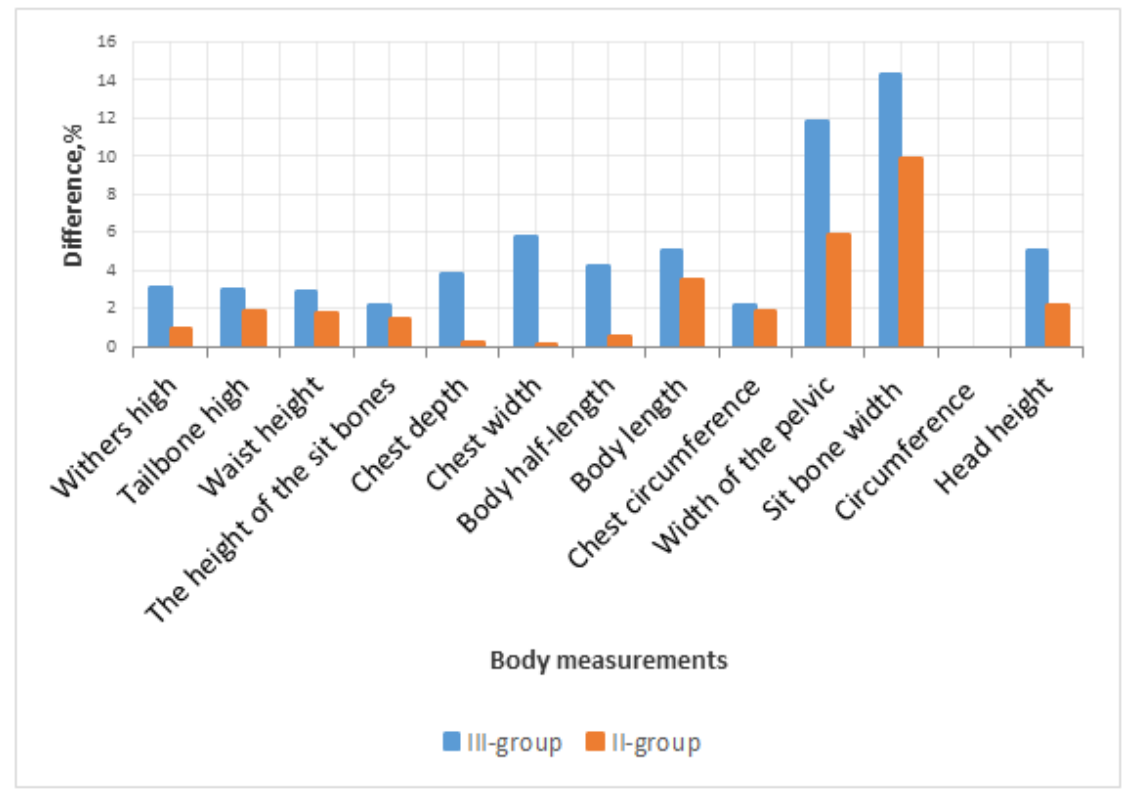

Fig. 1. Graphic differences in body size of young cattle in the experimental groups at 18 months $(100 \%$ of the body size of cattle in group I).

By studying the behavior of cattle, the intensity and proportion of physiological processes in their bodies, as well as productivity indicators were studied as a whole process. The timing of movements varies according to the group and age of the cattle. In particular, if we compare the duration of upright and lying down of cattle during the day, 
then the group III cattle on standing up at 12 months has an advantage. In them, the duration of standing was $65.1 \%$, while the duration of lying down was $34.9 \%$ (Table 4 ). These figures were 62.9 and $37.2 \%$ in the group II, respectively, and they were $63.9 \%$ and $36.1 \%$, in the group III $(\mathrm{P}>0.95)$.

Table 4. Timing of movement of young cattle in experimental groups $(X \pm S)$.

\begin{tabular}{|c|c|c|c|c|c|c|c|}
\hline \multirow{2}{*}{ Indicators } & \multirow{2}{*}{$\underset{\text { (month }}{\text { Age }}$} & \multicolumn{2}{|c|}{ I-group $(n=10)$} & \multicolumn{2}{|c|}{ II-group $(n=10)$} & \multicolumn{2}{|c|}{ III-group $(n=10)$} \\
\hline & & Minute & $\%$ & Minute & $\%$ & Minute & $\%$ \\
\hline \multirow{3}{*}{$\begin{array}{l}\text { Standing } \\
\text { upright }\end{array}$} & 12 & $905 \pm 10.09$ & 62.8 & $910.5 \pm 12.1$ & 63.9 & $935.7 \pm 13.1$ & 65.1 \\
\hline & 15 & $915.1 \pm 10.1$ & 63.5 & $896.1 \pm 11.3$ & 62.9 & $932.5 \pm 12.3$ & 64.8 \\
\hline & 18 & $872.6 \pm 12.7$ & 60.6 & $867.2 \pm 10.1$ & 60.2 & $897.0 \pm 11.5$ & 62.3 \\
\hline \multirow{3}{*}{ Lying } & 12 & $535.6 \pm 11.9$ & 37.2 & $529.5 \pm 9.8$ & 36.1 & $504.3 \pm 12.1$ & 34.2 \\
\hline & 15 & $524.9 \pm 10.1$ & 36.5 & $543.9 \pm 9.8$ & 37.1 & $507.5 \pm 10.9$ & 35.2 \\
\hline & 18 & $567.4 \pm 12.5$ & 39.4 & $572.8 \pm 10.8$ & 39.8 & $543.0 \pm 9.8$ & 37.7 \\
\hline \multicolumn{8}{|c|}{ Activeness in steps } \\
\hline \multirow{3}{*}{ Activeness } & 12 & \multirow{2}{*}{\multicolumn{2}{|c|}{$\frac{12509 \pm 61.7}{14222+659}$}} & \multicolumn{2}{|c|}{$11579 \pm 71.5$} & \multicolumn{2}{|c|}{$12021 \pm 68.1$} \\
\hline & 15 & & & \multicolumn{2}{|c|}{$12371 \pm 76.2$} & \multicolumn{2}{|c|}{$12875 \pm 69.8$} \\
\hline & 18 & \multicolumn{2}{|c|}{$13827 \pm 71.2$} & \multicolumn{2}{|c|}{$12173 \pm 68.7$} & \multicolumn{2}{|c|}{$13023 \pm 73.0$} \\
\hline
\end{tabular}

The experiments were conducted at the beginning (autumn) and end (spring) of the winter-feeding type. The air temperature was $18{ }^{\circ} \mathrm{C}$ and $17{ }^{\circ} \mathrm{C}$, humidity 65 and $74 \%$, respectively, and the wind speed was 4.3 and $4.8 \mathrm{~m} / \mathrm{sec}$. Body temperature at the age of 12 months was $38.5-38.9^{\circ} \mathrm{C}$ in groups, heart rate was $88-91$ times/minutes and respiration was 36-37 times/minutes. At 18 months it was 38.9-39.0, ${ }^{\circ} \mathrm{C}, 91-97$ times/minutes, and $40-44$ times/minutes, correspondingly (Table 5).

Table 5. Clinical performance of young cattle in experimental groups $(X \pm S)$.

\begin{tabular}{|c|c|c|c|c|c|c|}
\hline \multirow{3}{*}{ Indicators } & \multicolumn{2}{|c|}{ I-group $(\mathrm{n}=10)$} & \multicolumn{2}{|c|}{ II-group (n=10) } & \multicolumn{2}{|c|}{ III-group $(n=10)$} \\
\hline & & & Age of cat & month & & \\
\hline & 12 & 18 & 12 & 18 & 12 & 18 \\
\hline $\begin{array}{l}\text { Body temperature, } \\
{ }^{\circ} \mathrm{C}\end{array}$ & $38.5 \pm 0.2$ & $39.0 \pm 0.2$ & $38.6 \pm 0.2$ & $38.9 \pm 0.1$ & $38.9 \pm 0.1$ & $39.3 \pm 0.1$ \\
\hline $\begin{array}{l}\text { Heartrate, } \\
\text { beats/min. }\end{array}$ & $88.0 \pm 1.7$ & $93.0 \pm 1.4$ & $89.0 \pm 1.7$ & $97.0 \pm 1.3$ & $91.0 \pm 1.8$ & $99.0 \pm 1.3$ \\
\hline $\begin{array}{l}\text { Breathing, } \\
\text { times/min }\end{array}$ & $36.0 \pm 0.9$ & $40.0 \pm 1.0$ & $37.0 \pm 0.8$ & $44.0 \pm 1.0$ & $37.0 \pm 1.1$ & $41.0 \pm 1.0$ \\
\hline $\begin{array}{c}\text { Air temperature, } \\
{ }^{\circ} \mathrm{C}\end{array}$ & 18.0 & 17.0 & 18.0 & 17.0 & 18.0 & 17.0 \\
\hline Air humidity, $\%$ & 65 & 74 & 65 & 74 & 65 & 74 \\
\hline Wind speed $\mathrm{m} / \mathrm{sec}$. & 4.3 & 4.8 & 4.3 & 4.8 & 4.3 & 4.8 \\
\hline $\begin{array}{c}\text { Experimental } \\
\text { season }\end{array}$ & Autumn & Spring & Autumn & Spring & Autumn & Spring \\
\hline
\end{tabular}

In terms of total protein content, the first generation of black-and-white Holstein genotype (Group I) was not inferior to the second generation (Group II) of Holstein genotype and Chinese Holstein (Group III).Total protein levels of cattle increased at 18 months of age compared to 12 months of age. The increase was highest in group I and III cattle. Comparison of the albumins showed that they were predominated at 12 months of age in cattle. As for globulins, their levels were relatively elevated at 18 months of cattle (Table 6). 
Table 6. Morphological and biochemical parameters of the blood of young cattle in the experimental groups $(\mathrm{X} \pm \mathrm{S})$.

\begin{tabular}{|c|c|c|c|c|c|c|}
\hline \multirow{2}{*}{ Indicators } & \multicolumn{2}{|c|}{ I-group (n=10) } & \multicolumn{5}{c|}{ II-group (n=10) } & \multicolumn{2}{c|}{ III-group(n=10) } \\
\cline { 2 - 7 } & \multicolumn{5}{|c|}{ Age of cattle, month } \\
\cline { 2 - 7 } & $\mathbf{1 2}$ & $\mathbf{1 8}$ & $\mathbf{1 2}$ & $\mathbf{1 8}$ & $\mathbf{1 2}$ & $\mathbf{1 8}$ \\
\hline $\begin{array}{c}\text { Hemoglobin } \\
\text { content, g/\% }\end{array}$ & $11.5 \pm 0.19$ & $12.1 \pm 0.22$ & $11.1 \pm 0.18$ & $11.8 \pm 11.25$ & $11.0 \pm 0.17$ & $11.8 \pm 0.21$ \\
\hline $\begin{array}{c}\text { Erythrocytes } \\
\text { million/mm }\end{array}$ & $10.7 \pm 0.20$ & $11.8 \pm 0.20$ & $10.6 \pm 0.2$ & $11.4 \pm 0.2$ & $10.9 \pm 0.19$ & $11.5 \pm 0.23$ \\
\hline $\begin{array}{c}\text { Leukocytes, } \\
\text { min/mm }\end{array}$ & $10.3 \pm 0.2$ & $12.3 \pm 0.2$ & $11.6 \pm 0.2$ & $11.8 \pm 0.21$ & $11.6 \pm 0.17$ & $12.5 \pm 0.19$ \\
\hline $\begin{array}{c}\text { Total } \\
\text { protein, g/\% }\end{array}$ & $8.45 \pm 0.1$ & $9.51 \pm 0.1$ & $8.31 \pm 0.1$ & $8.92 \pm 0.1$ & $8.53 \pm 0.3$ & $9.55 \pm 0.2$ \\
\hline $\begin{array}{c}\text { Albulils, } \\
\text { g/\% }\end{array}$ & $3.35 \pm 0.1$ & $3.15 \pm 0.1$ & $3.32 \pm 0.1$ & $3.10 \pm 0.1$ & $3.20 \pm 0.2$ & $3.30 \pm 0.1$ \\
\hline $\begin{array}{c}\text { Total } \\
\text { globulins, } \\
\text { g/\% }\end{array}$ & $5.10 \pm 0.1$ & $6.30 \pm 0.8$ & $4.99 \pm 0.1$ & $5.92 \pm 0.1$ & $5.35 \pm 0.1$ & $6.15 \pm 0.1$ \\
\hline Sh.j.alpha & $1.60 \pm 0.1$ & $1.78 \pm 0.1$ & $1.62 \pm 0.1$ & $1.82 \pm 0.1$ & $1.62 \pm 0.1$ & $1.85 \pm 0.2$ \\
\hline Beta & $1.25 \pm 0.1$ & $2.02 \pm 0.1$ & $1.35 \pm 0.1$ & $1.92 \pm 0.2$ & $1.42 \pm 0.1$ & $1.98 \pm 0.1$ \\
\hline Gamma & $2.25 \pm 0.1$ & $2.50 \pm 0.1$ & $2.02 \pm 0.1$ & $2.08 \pm 0.1$ & $2.31 \pm 0.1$ & $2.32 \pm 0.1$ \\
\hline $\begin{array}{c}\text { A/G } \\
\text { coefficient }\end{array}$ & 0.65 & 0.65 & 0.66 & 0.53 & 0.60 & 0.54 \\
\hline
\end{tabular}

The milk yield of cows was $2650 \mathrm{~kg}$ much higher than the standard of black-and-white cows. In particular, the first generation of black-and-white Holstein genotype (1/2-1/2) (group I) gained $567 \mathrm{~kg}$ or $21.4 \%$, and the second generation of black-and-white Holstein genotype (1/4-3/4) (II- group) was up to $1047 \mathrm{~kg}$ or $39.5 \%$, and in Chinese Holsteins (group III) it was $1523 \mathrm{~kg}$ or $57.5 \%$ higher.

Cows in the experiment Group III outperformed other groups in terms of milk yield. Cows the group I were lagging behind by $956 \mathrm{~kg}(29.7 \%)$ and the group II cows was by $476 \mathrm{~kg}(12.9 \%)$. The group II cows of the Holstein genotype produced $480 \mathrm{~kg}(14.8 \%)$ more milk than group I ( $\mathrm{P}>0.95-0.9999)$. In particular, the live mass was $\mathrm{r}=0.23$ and 0.63 in milk production, and the amount of live mass fat was $r=0.15$ and 0.61 , and the live mass-milk fat was $r=0.30$ and 0.57 . The body composition type of cattle and the morphofunctional characteristics of the udder were improved. Adapted to the milking technology in the machine, the milking rate was increased from $1.41 \mathrm{~kg} / \mathrm{min}$ to $2.40 \mathrm{~kg} / \mathrm{min}$.

A new type of cows was formed. They were far superior to the standard performance of the black-and-white breed in terms of milk yield and milk fat. In particular, milk yield was increased by $1100-1848 \mathrm{~kg}(38-54 \%)$ and milk fat was by $50-81 \mathrm{~kg}$, which was equal to 41-66\% ( $>>0.99-0.999)$. 
Table 7. Milk yield of first calving cows.

\begin{tabular}{|c|c|c|c|c|c|c|}
\hline \multirow{2}{*}{ Indicators } & \multicolumn{6}{|c|}{ Experimental groups } \\
\hline & \multicolumn{2}{|c|}{ I $(n=10)$} & \multicolumn{2}{|c|}{ II $(n=10)$} & \multicolumn{2}{|c|}{ III $(n=10)$} \\
\hline \multirow{2}{*}{ Lactation } & $\mathbf{X} \pm \mathbf{S}$ & $\mathbf{C}_{\mathrm{v}}$ & $\mathrm{X} \pm \mathrm{S}$ & $\mathbf{C}_{\mathrm{v}}$ & $\mathrm{X} \pm \mathrm{S}$ & $\mathbf{C}_{\mathrm{v}}$ \\
\hline & \multicolumn{2}{|l|}{301} & \multicolumn{2}{|l|}{302} & \multicolumn{2}{|l|}{303} \\
\hline milk yields, weight & $3217 \pm 117$ & 6.08 & $3697 \pm 119$ & 10.09 & $4173 \pm 121$ & 8.09 \\
\hline the amount of fat, $\%$ & $3.63 \pm 0.05$ & 1.69 & $3.70 \pm 0.02$ & 1.02 & $3.71 \pm 0.03$ & 0.98 \\
\hline milk fat, $\mathrm{kg}$ & $116.8 \pm 2.1$ & 5.33 & $136.8 \pm 3.9$ & 8.02 & $154.8 \pm 3.60$ & 6.25 \\
\hline live weight, weight & $423.9 \pm 29.0$ & 18.26 & $437.5 \pm 21.0$ & 19.12 & $458.9 \pm 31.0$ & 12.25 \\
\hline Milk rates & $758.9 \pm 17.0$ & 16.42 & $845.0 \pm 25.0$ & 12.22 & $909.3 \pm 23.0$ & 11.36 \\
\hline \multicolumn{7}{|c|}{ Including the productivity of leading cows $(n=4)$} \\
\hline Milk yields, weight & $3371.0 \pm 119$ & 11.06 & $3953.0 \pm 121$ & 13.07 & $4492.0 \pm 124$ & 13.81 \\
\hline the amount of fat, $\%$ & $3.62 \pm 0.04$ & 1.06 & $3.65 \pm 0.02$ & 1.05 & $3.69 \pm 0.02$ & 0.05 \\
\hline milk fat, weight & $122.2 \pm 2.0$ & 3.22 & $144.9 \pm 4.2$ & 3.56 & $163.4 \pm 3.91$ & 2.36 \\
\hline lactation & 302 & & 302 & & 303 & \\
\hline body weight, $\mathrm{kg}$ & $421.0 \pm 25.5$ & 9.56 & $436.0 \pm 20.4$ & 10.02 & $457.8 \pm 30.9$ & 15.02 \\
\hline Milk rates & $799.4 \pm 18.1$ & 7.88 & $916.4 \pm 27.9$ & 8.73 & $980.0 \pm 28.9$ & 10.33 \\
\hline
\end{tabular}

\section{Conclusion}

The nutritional value of experimental groups in the care and storage of young cattle (6-24 months) and heifers in the focused technology was 2997, 3160 and 3301 feed units, 3516 $\mathrm{kg} 3752$ and $3950 \mathrm{~kg}$ of dry matter and $550 \mathrm{~kg}, 580$ and $612 \mathrm{~kg}$ of digestible protein. In the feed type, the weight of concentrated nutrients was maintained at $8.5-9.3 \%$. The nutrients consumed was different in the experimental groups. It was assumed that group I was $100 \%$, group II was equal to $105.4 \%$ and group III was equal to 110.1 feed units. Per $1 \mathrm{~kg}$ of feed per group was 183, 183, 185 grams, respectively. The protein-sugar ratio was 1: 0.47-0.48. Dry matter per $1 \mathrm{~kg}$ of feed unit was $1.17-1.20 \mathrm{~kg}$, followed by 12.2-12.5 MJ of exchange energy, 362-370 grams of fiber and 87-90 grams of sugar. Improvement of cattle had a positive effect on the rise of their living mass and the improvement of their exterior properties.

Cattle of high Holstein genotype was dominant in the economic efficiency of milk production. The net profit was 961.9 thousand sums in the group I, followed by 1257 thousand sums in the group II, 1821 thousand sums in the group III. The level of profitability in those groups was $29.9 \%, 35.4 \%$, and $46.7 \%$, respectively.

\section{References}

1. President Decree No. 4947 of the Republic of Uzbekistan on "the Action Strategy for the five priority areas of further development of the Republic of Uzbekistan for 20172021", on Feburary 7 (2017)

2. Decree of the Cabinet of Ministers No. 4243 of the Republic of Uzbekistan on "Measures for further development and support of the livestock sector", on March 18 (2019) 
3. Decree of the Cabinet of Ministers No. 2460 of the Republic of Uzbekistan on "Measures to further reform and develop agriculture in 2016-2020", on December 29, (2015)

4. E. Kašná, L. Zavadilová, E. Krupa, Z. Krupová, A. Kranjčevičová, Czech Journal of Animal Science, 65, 12 (2020)

5. M. Dosmukhamedova, U. Nosirov, Q. Shakirov G. Mamurov, A. Esanov, International Journal of Research Development, 4, 5 (2019)

6. M. Dosmukhamedova, U. Nosirov, U. Khodjaev, International journal of advanced research, 7, 5 (2019)

7. B. Wu, L. Zan, Reproduction in domestic animals, 47(5), 865-871 (2019)

8. O. Mamatkulov, M. Dosmukhamedova, U. Nosirov, International journal for innovative research, 5, 5 (2019).

9. M. Dosmukhamedova, Q. Shakirov, S. Isroilov, Livestock and breeding, 1, 7 (2019)

10. M. Ashirov, U Soatov, International Multidisciplinary Research journal, 10, 8 (2020)

11. M. Ashirov, U. Soatov, Dairy and beef cattle breeding, 6 (2015)

12. M. Ashfaq, R. Kousar, M. Makhdum, J. Nasir, Journal of Animal and Plant Sciences, 30, 6 (2020)

13. W. Hartmann, J. Pereira, Reproduction Biotechnology in Farm Animals, 155 (2018)

14. Z. Krupová, E. Krupa, M. Wolfová, Czech Journal of Animal Science, 65, 3 (2020)

15. O. Gorelik, E. Likhodeevskaya, N. Zezin, M. Sevostyanov, O. Leshonok, IOP Conference Series: Earth and Environmental Science, 548, 8 (2020) 